\title{
Study on Scientific Attitude of B.Ed., Trainees in Perambalur District
}

\section{OPEN ACCESS}

Manuscript ID:

EDU-2020-08043251

Volume: 8

Issue: 4

Month: September

Year: 2020

P-ISSN: 2320-2653

E-ISSN: 2582-1334

Received: 13.06.2020

Accepted: 18.07.2020

Published: 01.09.2020

Citation:

Rajendran, P., and R. Anandarasu. "Study on Academic Self Image of B.Ed., Trainees in Perambalur District." Shanlax International Journal of Education, vol. 8 , no. 3, 2020, pp. 105-110.

DOI:

https://doi.org/10.34293/ education.v8i4.3251

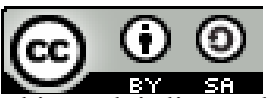

This work is licensed under a Creative Commons Attribution-ShareAlike 4.0 International License

\author{
P. Rajendran \\ Ph.D. Scholar, Department of Education, Tamil University, Thanjavur, Tamil Nadu, India \\ https://orcid.org/0000-0002-6311-7383
}

\section{R. Anandarasu}

Assistant Professor, Department of Education, Tamil University, Thanjavur, Tamil Nadu, India

\begin{abstract}
The study was intended to find out the level of Scientific Attitude of B.Ed., trainees in the Perambalur district. This study involves a survey method. The size of the sample in the study was 941 B.Ed., trainees who were selected through the simple random sampling technique. The main objectives of the study are to find out the Scientific Attitude of B.Ed., trainees concerning the Demographic variables such as gender, year of study, locality of college, type of family. The Statistical procedures used in this study were; Mean, Standard Deviation, and' test to analyze the data. The Major findings of the study were; i). The level of Scientific Attitude of B.Ed., Trainees, is average. ii) Female B.Ed., Trainees, is a significantly higher level of Scientific Attitude than the Male B.Ed., Trainees. iii) Second Year B.Ed., Trainees are a significantly higher level of Scientific Attitude than the First Year B.Ed., Trainees. iv) Urban B.Ed., Trainees, is a significantly higher level of Scientific Attitude than the Rural B.Ed., Trainees. v) Nuclear Family and Joint Family of B.Ed., Trainees, are having a similar level of Scientific Attitude. It's my conclusion that the present study reveals that there is more number of B.Ed., Trainees have an average Scientific Attitude. Keywords: Attitude, Scientific Attitude, Science Teaching, Science, open-minded attitude and B.Ed trainees
\end{abstract}

\section{Introduction}

Education is the main instrument for any social change, and science education plays a vital role in any educational system. Time and again, our educational committees, commissions, and policies have identified the place and importance of science education. It is only through the development of scientific attitude among the students; we, the teachers, will be able to develop and nourish the all-round personality of our students. Science is an organized body of knowledge with careful observation and experimentation. In other words, we can say that science is an overall product of human activity in a systematic and organized way. Science is nothing but a curiosity of knowing, which suitable explanation in an organized and planned way. Scientific attitude is one of the key objectives of science teaching, and it is one of the major outcomes of it. Scientific attitude makes people live as efficient citizens in the present society. It also helps people live up to their expectations and satisfaction. Many ways and means are used and applied to develop scientific attitudes at various levels of education.

\section{Need for the Study}

Science attitudes are important because of three important factors. First, a child's attitude carries a mental state of readiness with it. With a positive attitude, a child will perceive science objects, topics, activities, and positively. A child, who is unready or hesitant for whatever reason, will be less willing to interact with people and things associated with science. Second, attitudes are 
not innate or inborn. Contemporary psychologists maintain that attitudes are learned and organized through experience as a child develops.

Furthermore, a child's attitude can be changed through experience. Teachers and parents have the furthermost pressure on science attitudes. Thirdly attitudes are dynamics result of experiences that act as directive factors when a child enters into a new experience. As a result, attitude carries an emotional and intellectual tone, both of which lead to making decisions and forming evaluations. These decisions and evaluation can cause a child to set up priorities and hold different preferences.

Attitudes determine the negative or positive character of our responses to various kinds of stimuli or diverse types of situations. Their importance in life cannot be overstated. Attitudes offer greater possibilities for the success of achievement as well as failure in life. They are an important motivator of behavior and affect human values. Efficiency results, when a person is impelled by his attitude to start, continue, and complete a project rather than to avoid an unpleasant task, his attitude towards his work affects his work wholeness in the activity. Hence, there is a felt need to study, Study on Scientific Attitude of B.Ed., trainees in perambalur district.

\section{Research Studies}

Erdogan, Sezen Camci (2018) The purpose of this study is to determine the science teaching attitudes and scientific attitudes of pre-service teachers of gifted students due to gender and grade level and also a correlation among these variables. It is a survey study that the group is 82 students attending the Gifted Education undergraduate level. Data is gathered by the Scientific Attitude Inventory, SAI II, and Science Teaching Attitude Scale. Then data is analyzed by independent samples t-test, ANOVA, correlation, and regression statistical methods. In conclusion, there is a significant difference due to grade level, and there is a high correlation between scientific attitudes and science teaching attitudes. In this context, it is recommended that a learning environment that positively affects scientific attitudes and science teaching attitudes should be organized.

Singh, Singh, and Geri (2017) studied the relationship between scientific attitude and academic achievement of rural area's intermediate college girls of science stream only in Varanasi district of Uttar Pradesh. A total of 75 female students studying in class XI (Science stream only) were selected from colleges as the sample of the study. Here the type of sampling was accidental sampling. To measure the scientific attitude of XI class female students, a questionnaire developed by Prof. K.S. Mishra, Education department, Allahabad University, was used to collect data. It measures scientific attitude as manifested in action and intent form. The study revealed that academic achievement was positive, as well as significantly correlated with a scientific attitude. It means that with an increase in academic achievement, the scientific attitude of female students also increases. The finding may lie in the fact that at the higher secondary level overall scientific attitude develops among the students in its optimal level; it seems that students having scientific attitude will be critical minded, honest, objective, ready to change opinion, open-minded and possess questioning attitude and respect evidence, which are essential for optimum academic achievement mainly in science subjects.

Jeyanthi (2016) conducted a study on scientific attitude and achievement in the science of upper primary school students. The investigator chose 200 upper primary school students in Dindigul district as a sample by using a simple random sampling technique and used Baskara Rao's scientific attitude scale (SAS) as a tool. The major findings of the study were: 1. there was no significant difference between boys and girls, rural and urban, and government and aided school students. It means gender, locality, and type of school have not influenced the scientific attitude among middle school students. 2 . There was a significant relationship between scientific attitude and academic achievement concerning gender, location, and type of school management at 0.01 level of significance.

\section{Objectives of the Study}

The following objectives were framed for the present research study.

- To find out the level of scientific attitude of B.Ed., trainees.

- To find out the significant difference in the Mean Scores of the level of scientific attitude of B.Ed., 
trainees concerning the Demographic variables such as gender, year of study, locality of college, type of family.

\section{Hypotheses of the Study}

The Hypotheses of the study are given below.

- The level of scientific attitude of B.Ed., trainees, are high.

- There is no significant difference in the mean scores on the level of scientific attitude of B.Ed., trainees concerning the Demographic variables such as gender, year of study, locality of college, type of family.

\section{Methodology}

The study belongs to a Survey Method, as it is indented to find out the level of scientific attitude of B.Ed., trainees.

\section{Selection and Size of the Sample}

The investigator had selected 941 B.Ed., trainees as a sample by Simple Random Sampling Technique from Perambalur District.

\section{Tool used in this Study}

Scientific Attitude Scale was Developed and Standardized by the investigator with the help of the supervising our Guide. The Reliability Coefficient is 0.84 measured by the split-half method. The tool has 45 items with five alternative responses; Strongly Agree, Agree, Undecided, Disagree, and Strongly Disagree. For Positive statements, the scoring of 5, $4,3,2,1$, and negative items are scored in the reverse order.

\section{Data Collection Procedure}

The investigator got prior permission from the principal of the college approached, the B.Ed., trainees of the college for getting necessary cooperation. I am explaining the purpose of the research title as; study on the scientific attitude of B.Ed., Trainees. I am provided with the tool of Photocopies. The investigator explained the tool and the way of answering the questionnaire. The questionnaire was administered individually to all the student's teachers.

\section{Data Analysis}

The investigator followed Mean, Standard Deviation, ' $t$ ' Test for the analysis of the data. The results were presented in the following tables.

\section{Hypothesis 1}

The level of Scientific Attitude of B.Ed., Trainees, is high.

\section{Table 1: Mean and Std. Deviation Scores on the level of Scientific Attitude of \\ B.Ed., Trainees in Total}

\begin{tabular}{|c|c|c|c|c|c|}
\hline S. No & \multicolumn{2}{|c|}{ Variables } & $\mathbf{N}$ & Mean & SD \\
\hline 1 & \multicolumn{2}{|c|}{ Total } & 941 & 145.77 & 13.30 \\
\hline \multirow{2}{*}{2} & \multirow{2}{*}{ Gender } & Male & 210 & 143.12 & 12.83 \\
\hline & & Female & 731 & 146.53 & 13.34 \\
\hline \multirow[b]{2}{*}{3} & \multirow{2}{*}{$\begin{array}{l}\text { Year of } \\
\text { Study }\end{array}$} & First Year & 410 & 143.36 & 12.83 \\
\hline & & $\begin{array}{l}\text { Second } \\
\text { Year }\end{array}$ & 531 & 147.63 & 13.36 \\
\hline \multirow{2}{*}{4} & \multirow{2}{*}{$\begin{array}{l}\text { Locality } \\
\text { of } \\
\text { College }\end{array}$} & Rural & 450 & 143.32 & 12.18 \\
\hline & & Urban & 491 & 148.01 & 13.89 \\
\hline \multirow{2}{*}{5} & \multirow{2}{*}{$\begin{array}{l}\text { Type of } \\
\text { Family }\end{array}$} & $\begin{array}{l}\text { Nuclear } \\
\text { Family }\end{array}$ & 544 & 146.37 & 12.71 \\
\hline & & $\begin{array}{l}\text { Joint } \\
\text { Family }\end{array}$ & 397 & 144.94 & 14.04 \\
\hline
\end{tabular}

From table 1, the obtained Maximum and Minimum Mean and SD of the Scientific Attitude are 148.01 and 147.63 and 14.04 and 13.89. It is also revealed that the Mean and SD of the Scientific Attitude score of the total sample were 145.77 and 13.30. It shows that the level of Scientific Attitude of B.Ed., Trainees is average.

\section{Hypothesis 2}

There is no significant difference in the Mean scores on the level of Scientific Attitude of B.Ed., Trainees concerning their Gender.

Table 2: ' $t$ ' value in the Mean scores on the level of Scientific Attitude of B. Ed., Trainees concerning their Gender

\begin{tabular}{|c|c|c|c|c|c|}
\hline S. No & Gender & N & Mean & SD & $\begin{array}{c}\text { 't' } \\
\text { value }\end{array}$ \\
\hline 1 & Male & 210 & 143.12 & 12.839 & \multirow{2}{*}{$3.293 *$} \\
\hline 2 & Female & 731 & 146.53 & 13.343 & \\
\hline
\end{tabular}

* Significant at 0.05 level 
It is seen from the above Table 2 that the ' $\mathrm{t}$ ' value 3.293 is Significant at the 0.05 level. It is understood from the result that there is a significant difference in the level of Scientific Attitude of B.Ed., Trainees concerning their Gender. Female B.Ed., Trainees, is a significantly higher level of Scientific Attitude than the Male B.Ed., Trainees. Hence the null hypothesis is rejected.

\section{Hypothesis 3}

There is no significant difference in the Mean scores on the level of Scientific Attitude of B.Ed., Trainees concerning their Year of Study.

Table 3: ' $t$ ' value in the Mean scores on the level of Scientific Attitude of B.Ed., Trainees concerning their Year of Study

\begin{tabular}{|c|c|c|c|c|c|}
\hline $\begin{array}{c}\text { S. } \\
\text { No }\end{array}$ & $\begin{array}{c}\text { Year of } \\
\text { Study }\end{array}$ & N & Mean & SD & $\begin{array}{c}\text { 't' } \\
\text { value }\end{array}$ \\
\hline 1 & First Year & 410 & 143.36 & 12.83 & \multirow{2}{*}{$4.951^{*}$} \\
\hline 2 & Second Year & 531 & 147.63 & 13.36 & \\
\hline
\end{tabular}

* Significant at 0.05 level

It is seen from the above Table 3 that the ' $t$ ' value 4.951 is Significant at the 0.05 level. It is understood from the result that there is a significant difference in the level of Scientific Attitude of B.Ed., Trainees concerning their Year of Study. Second Year B.Ed., Trainees are the significantly higher level of Scientific Attitude than the First Year B.Ed., Trainees. Hence the null hypothesis is rejected.

\section{Hypothesis 4}

There is no significant difference in the Mean scores on the level of Scientific Attitude of B.Ed., Trainees concerning their Locality of College.

Table 4: ' $t$ ' value in the Mean scores on the level of Scientific Attitude of B.Ed., Trainees concerning their Locality of College

\begin{tabular}{|c|c|c|c|c|c|}
\hline $\begin{array}{c}\text { S. } \\
\text { No }\end{array}$ & $\begin{array}{c}\text { Locality of } \\
\text { College }\end{array}$ & N & Mean & SD & ' $t$ ' value \\
\hline 1 & Rural & 450 & 143.32 & 12.18 & \multirow{2}{*}{$5.491 *$} \\
\hline 2 & Urban & 491 & 148.01 & 13.89 & \\
\hline
\end{tabular}

* Significant at 0.05 level

It is seen from the above Table 4 that the ' $\mathrm{t}$ ' value 5.491 is Significant at the 0.05 level. It is understood from the result that there is a significant difference in the level of Scientific Attitude of B.Ed., Trainees concerning their Locality of College. Urban B.Ed., Trainees, are the significantly higher levels of Scientific Attitude than the Rural B.Ed., Trainees. Hence the null hypothesis is rejected.

\section{Hypothesis 5}

There is no significant difference in the Mean scores on the level of Scientific Attitude of B.Ed., Trainees concerning their Type of Family.

Table 5: ' $t$ ' value in the Mean scores on the level of Scientific Attitude of B.Ed., Trainees concerning their Type of Family

\begin{tabular}{|c|c|c|c|c|c|}
\hline $\begin{array}{c}\text { S. } \\
\text { No }\end{array}$ & Type of Family & N & Mean & SD & $\begin{array}{c}\text { 't' } \\
\text { value }\end{array}$ \\
\hline 1 & Nuclear Family & 544 & 146.37 & 12.71 & \multirow{2}{*}{$1.626^{* *}$} \\
\hline 2 & Joint Family & 397 & 144.94 & 14.04 & \\
\hline
\end{tabular}

Table 5 reveals that the ' $t$ ' value 1.626 is Not Significant at the 0.05 level. It is understood from the result that there is no significant difference in the level of Scientific Attitude of B.Ed., Trainees concerning their Type of Family. Nuclear Family and Joint Family of B.Ed., Trainees, are having a similar level of Scientific Attitude. Hence, the null hypothesis is found to be accepted.

\section{Findings of the Study}

The findings of the present study are presented below. They are as follows

1. The level of Scientific Attitude of B.Ed., Trainees, is average.

2. Female B.Ed., Trainees, are the significantly higher level of Scientific Attitude than the Male B.Ed., Trainees.

3. Second Year B.Ed., Trainees are the significantly higher level of Scientific Attitude than the First Year B.Ed., Trainees.

4. Urban B.Ed., Trainees, are the significantly higher level of Scientific Attitude than the Rural B.Ed., Trainees.

5. Nuclear Family and Joint Family of B.Ed., Trainees, are having a similar level of Scientific Attitude. 


\section{Discussion of the Study}

It is found that there is a significant difference between scores on the scientific attitude of B.Ed., trainees concerning their gender. The findings of Female B.Ed., Trainees, are the significantly higher level of Scientific Attitude than the Male B.Ed., Trainees. Similar to the findings of Jeyanthi (2016) conducted a study on scientific attitude and achievement in the science of higher secondary school students in Dindigul district.

It is found that there is a significant difference between scores on the scientific attitude of B.Ed., trainees concerning their locality of college. The findings of the result of that the scientific attitude of Urban B.Ed., Trainees is higher than the mean score of rural B.Ed., Trainees. Therefore Urban B.Ed., Trainees have a better scientific attitude as compared to rural B.Ed., Trainees. Similar to the findings of Ali (2014), he investigated the scientific attitude of adolescent students in the Visakhapatnam district in Andhra Pradesh.

\section{Recommendations of the Study}

- To develop the Scientific Attitude of Trainees should be free to attempt their patterns of exploration.

- Teacher educators should create interest in science teaching by organizing science exhibitions and science fairs. Scientific magazines, journals, and Innovative inventions, etc., should be in college.

- Discovery and Constructivist approaches should replace the conventional method in science teaching.

- The student teacher's home learning environment transitions into a structured learning environment are necessary for parents.

\section{Suggestions for Further Research}

Based on the findings of the present study, further studies are suggested to be conducted in the future are as given below:

- The present study was confined to the B.Ed., student teachers, whereas, Similar studies may be conducted on Students at School Level

- The study may also be conducted with different Colleges such as; Arts and Science Colleges, Medical and Engineering.

\section{Conclusion}

The present study reveals that there is more number of B.Ed., Trainees who are having an average scientific attitude. Development of Scientific Attitude among B.Ed., Trainees, is an important factor for increasing their academic achievement, especially in Science subjects. It would help in nurturing them with an open-minded attitude, which would enable them to search for truth and developing the desire to acquired correct knowledge. Such an attitude would help these learners to solve problems in their everyday life in a scientific manner. Therefore, the Investigator hopes that the present study would surely help to understand B.Ed., Trainees better so that remedial measures for those lack in this area may be given an improvement and support to those having a high level of Scientific Attitude.

\section{References}

Akporehwe, J.N. and F.A. Onwioduokit. "Enhancing Scientific Attitudes through Activity based approach." Nigerian Journal of Science and Science Education, vol. 8, no. 2, 2010, pp. 87 102.

Ataha, Utibe C., and Augustine E. Ogumogu. "An Investigation of the Scientific Attitude among Science Students in Senior Secondary Schools in Edo South Senatorial District, Edo State." Journal of Education and Practice, vol. 4, no. 11, 2013, pp. 12- 16.

Best, John. W, and James V. Kahn. Research in Education, Prentice-Hall, 1989.

Erdogan, Sezen Camci. "Science Teaching Attitudes and Scientific Attitudes of Pre-Service Teachers of Gifted Students." Journal of Education and Practice, vol. 8, no. 6, 2017, pp. 164-170.

Gokul Raj, R., and T. Malliga. "A Study on Scientific attitude among Pre-service Teachers." Research Journal of Recent Sciences, vol. 4, 2015, pp. 196-198.

Jancirani, R., et al. "A Study on Scientific Attitude of Adolescence Students in the Namakkal District." International Educational E-Journal, vol. I, no. IV, 2012, pp. 2-8.

Jeyalatha, T., and K. Anandan. Effectiveness of Blended Teaching on Achievement in Science 
in Relation to Scientific Attitude and SocioEconomic Status among the Students of Higher Secondary Schools, Bharathidasan University, 2016.

Kalra, R.M. Innovations and Science Teaching, Oxford IBH Publishing Ltd., 1976.

Mohanty, Susandhya. Teaching of Science in Secondary Schools, Deep \& Deep publications, 1997.

Nanda, V.K. (2002). The teaching of general Science, New Delhi: Anmol Publications Pvt. Ltd.

Pitafi, Amjad Islam and Muhammad Farooq. "Measurement of the Scientific Attitude of Secondary School Students in Pakistan." Academic Research International Journal, vol. 2, no. 2, 2012, pp. 379-392.
Rao, D. Bhaskara. Scientific Attitude, Scientific Aptitude, and Achievement, Discovery Publishing House, 2010.

Sharma, I. "Problem-solving Abilities and Scientific Attitude as Determinant of Academic Achievement of Higher Secondary Students." Journal of all India Association for Educational Research, 2007, pp. 68-69.

Srivastava, Stuti. “A Study of Relationship between Environmental Moral Reasoning and Scientific Attitude among Secondary Students." Online International Interdisciplinary Research Journal, vol. III, no. IV, 2013, pp. 134-139.

Tulasi, Padma and Bhaskara Rao. Method of Teaching Elementary Science, Discovery Publishing House, 2004.

\section{Author Details \\ P. Rajendran, Ph.D. Scholar, Department of Education, Tamil University, Thanjavur, Tamil Nadu, India \\ EmailID: rajendhp@gmail.com.}

R. Anandarasu, Assistant Professor, Department of Education, Tamil University, Thanjavur, Tamil Nadu, India 